\title{
НОРМАТИВНЫЕ ПРАВОВЫЕ ОСНОВЫ МОНИТОРИНГА ПРАВОПРИМЕНЕНИЯ: ФЕДЕРАЛЬНЫЙ И РЕГИОНАЛЬНЫЙ УРОВНИ
}

\author{
(C) 2021 Ларионова Карина Азатовна \\ аспирант \\ Астраханский государственный университет, Россия, Астрахань
}

В статье сконцентрировано внимание на анализе нормативных правовых актов, регламентирующих вопросы организации мониторинга правоприменения. В сферу исследования попали нормативные документы федерального и регионального уровней, сформированы принципиальные подходы к различным путям формирования направлений организации мониторинга правоприменения в регионах.

В работе представленная авторская позиция о классификации нормативных актов, регламентирующих процесс мониторинга правоприменения, которая позволила проиллюстрировать слабые стороны повышения эффективности правовых актов за счет организации мониторинга правоприменения и представит предложения о законодательной корректировке правовых основ мониторинга правоприменения.

Ключевые слова: мониторинг правоприменения, нормативный правовой акт, федеральные правовые акты, региональные правовые акты.

Интенсивность развития законодательства в последнее время ставит новые вызовы перед государством в части повышения юридической техники и юридического предвидения. Часто меняющиеся потребности общества нуждаются в детализированной регламентации. В попытках решить поставленные задачи государственный аппарат увеличивает объем принимаемых разноуровневых нормативных правовых актов, что неизбежно порождает возникновение казуистики, дефектов содержания правовых актов, проявляющихся в процессе практики правоприменения. Коррекция возможных норм права возможна с учетом активации правового мониторинга, направленного на выявление вышеобозначенных сложностей.

Цель исследования заключается в комплексом анализе нормативных правовых основ мониторинга правоприменения, сформированных на федеральном и региональном уровнях.

Основным методом, используемым при проведении исследования, был избран метод научной объективности, который предполагает учет всей совокупности факторов, влияющих на формирование и реализацию правовых основ института правового мониторинга в целом и мониторинга правоприменения в частности. Проблематика исследования также требует использования общенаучных и частнонаучных методов (анализ, синтез, а также метод сравнительного исследования).

Целевое назначение правового мониторинга заключается в комплексном функционировании государственных и муниципальных органов в области исследования целевого назначения, структуры правовой нормы, ее взаимосвязи с иными, в особенности вышестоящими по иерархии, правовыми актами. Однако, следует отметить, что доктринальное восприятие правового мониторинга и его нормативное закрепление не совпадают по ключевым точкам реализационного процесса. Так, большинство авторов видят комплексность правового мониторинга, проявляющуюся в исследовании «жизни» правового акта на всех этапах его существования, начиная с инициативы [1].

В противовес указанному к настоящему времени сложилась нормативная ситуация, при которой законодатель видит правовой мониторинг только на последнем этапе, то есть, организуя мониторинг правоприменения.

Указанный тезис подтверждается детальным анализом нормативных правовых документов как на федерльном, так и на региональном уровнях.

В современной правовой действительности нормативным фундаментом правового мониторинга как механизмом повышения эффективно- 
сти функционирования правовых актов выступают на федеральном уровне:

- Указ Президента РФ от 20.05.2011 № 657 (ред. от 25.07.2014) «О мониторинге правоприменения в Российской Федерации» [2];

- Постановление Правительства Российской Федерации от 19.08.2011 № 694 «Об утверждении методики осуществления мониторинга правоприменения в Российской Федерации» [3].

Функционирование всей системы мониторинга правовых актов в части повышения их эффективности основано именно на представленных нормативных документах. В то же время законодатель уделил внимание и специфичному мониторингу правовых актов. Так в особенности необходимо уделить внимание Федеральному закону «Об антикоррупционной экспертизе нормативных правовых актов и проектов нормативных правовых актов» [4]. На федеральном уровне определяется необходимость организации мониторинга правовых актов по факту эксплуатации правовой нормы в коррупционных целях. При этом стоит акцентировать внимание, что в этом контексте антикоррупционная экспертиза выступает в качестве своеобразного проявления криминологической экспертизы.

По содержанию мониторинг связан с возможным применением нормы при организации коррупционных схем, по этой причине комплексный механизм антикоррупционной экспертизы входит в состав масштабного правового явления противодействия коррупции. Исследуя правовые основы указанного процесса, следует обратить внимание на документ, регламентирующий правила организации антикоррупционной экспертизы. К таковому относится Постановление Правительства «Об антикоррупционной экспертизе нормативных правовых актов и проектов нормативных правовых актов» [5]. Документ позволяет запустить в действие весь механизм антикоррупционной экспертизы, регламентирует правила ее осуществления и детализирует весь механизм. Следует отметить, что, по мнению О.А.Бородиной, особая роль в организации антикоррупционной экспертизы нормативных актов отведена прокуратуре, в которой видится особое экспертное значение выявления коррупционных дефектов функционирования правовых документов [6]. Кроме того, в работе О.А.Бородиной делается акцент на независимости указанного вида экспертизы, что может повысить эффективность рассматривае- мой разновидности правового мониторинга, а, следовательно, автоматически соответствовать основной цели правового мониторинга - повысить качество нормативных правовых актов на основании мониторинга правоприменения.

Следует констатировать, что мониторинг правоприменения регламентируется не только и не столько на федеральном уровне, сколько имеет реальные праворегуляторы на региональном уровне. В качестве примера можно привести закон Тамбовской области [7], Краснодарского края [8], Свердловской области [9], Республики Алтай [10], Липецкой области [11], Республики Крым [12], Астраханской области [13] и многие другие.

Анализ перечисленных нормативных актов регионального значения позволяет заключить, что вопросы правового мониторинга решаются в двух плоскостях. В одних регионах сформированы правовые основы организации мониторинга на всех этапах «жизни» правового акта (начиная с инициативы). К таковым следует отнести законы Тамбовской области, Краснодарского края, Свердловской области, Республики Крым, Липецкой области. В других - процесс мониторинга сконцентрирован и регламентирован мониторингом правоприменения. К таковым относятся из представленных нормативные документы Республики Алтай, Астраханской области.

Таким образом, следует констатировать два пути повышения на региональном уровне эффективности нормативных актов:

- в комплексе организации правового мониторинга нормативных актов на всех этапах их существования (от инициативы и процесса нормотворчества до мониторинга правоприменения);

- нормативно-правовое регулирование обособленного процесса мониторинга правоприменения как инструментария повышения эффективности правовых актов.

В рамках организованного правового исследования нормативных правовых основ мониторинга правоприменения на федеральном и региональном уровнях представляется возможным сконструировать авторскую гипотезу о формировании классификации норморегуляторов мониторинга правоприменения, которую рационально представить в следующем виде:

1. В зависимости от уровня субъекта, принявшего акт, делятся на 
- федеральные акты;

- региональные акты.

2. В зависимости от объекта правового регулирования в процессе мониторинга правоприменения:

- акты, регламентирующие процесс организации мониторинга правоприменения в целом (Указ Президента Российской Федерации от 20.05.2011 № 657 «О мониторинге правоприменения в Российской Федерации», Постановление Правительства Российской Федерации от 19.08.2011 № 694 «Об утверждении методики осуществления мониторинга правоприменения в Российской Федерации»);

- акты, регламентирующие организацию мониторинга правоприменения по определенным формам проявления дефектности правовых документов (Федеральный закон от 17.07.2009 г. № 172-Ф3 «Об антикоррупционной экспертизе нормативных правовых актов и проектов нормативных правовых актов», Постановление Правительства от 26.02.2010 г. № 96 «Об антикоррупционной экспертизе нормативных правовых актов и проектов нормативных правовых актов»).

3. Региональные нормативные акты, в зависимости от охвата праворегулирования следует разделить на:

- акты, регламентирующие процесс правового мониторинга на всех этапах «жизни» нормативного акта - от инициативы до мониторинга правоприенения (Закон Тамбовской области от 23.06.2006 № 51-3 «О правовых актах Тамбовской области», Закон Свердловской области от 17.10.2013 № 84-О3 «О мониторинге законодательства Свердловской области и мониторинге практики его применения»);

- акты, действие которых направлено на организацию только мониторинга правоприменения, как обособленной формы правового мониторинга, реализуемого с целью повышения эффективности функционирования нормативных актов (Закон Республики Алтай от 04.10.2012 № 49-Р3 «О мониторинге правоприменения нормативных правовых актов в Республике Алтай», Постановление Правительства Астраханской области от 29.09.2011. № 393-П «О мониторинге правоприменения», Постановление Губернатора Астраханской области от 26.10 .2011 № 415 «О государственно-правовом управлении администрации Губернатора Астраханской области»).

Представленная классификация оголяет проблему безсистемности отечественного законодательства в вопросах организации правового мониторинга в целом и мониторинга правоприменения в частности. Анализ нормативных документов позволяет констатировать тот факт, что отсутствие на федеральном уровне обособленного нормативного правового акта об организации правового мониторинга, который мог бы быть сформирован и как отдельный правовой документ, и в составе нормативного акта о нормативных правовых актах в целом, не позволяет оформить единообразную государственную политику в области повышения эффективности функционирования нормативных актов, что, безусловно, влечет к реализации дефектных правовых норм.

Представленная проблематика разрешима в рамках инициативы по формированию нормативного документа, включающего в себя все этапы организации правового мониторинга и включения мониторинга правоприменения в качестве составной части юридической категории «правовой мониторинг».

\section{Библиографический список}

1. Баринов А.М., Меньшикова Г.А., Евстратчик С.В. Мониторинг правоприменения и оценка регулирующего воздействия: новому обществу - новые технологии управления // Мониторинг правоприменения. 2019. № 3 (32). С. 63-69; Фадеева Е. С. Принципы правового мониторинга институтов власти // Мониторинг правоприменения. 2019. № 4 (33). С. 23-28; Лукьянова В.Ю. Юридические технологии правового анализа // Журнал российского права. 2018. № 11 (263). С. 25-40; Боуш К. С. Мониторинг правоприменения и антикоррупционная экспертиза // Вестник Казанского юридического института МВД России. 2018. № 3 (33). С. 321-326.

2. Указ Президента Российской Федерации от 20.05.2011 № 657 (ред. от 25.07.2014) «О мониторинге правоприменения в Российской Федерации» // Собрание законодательства РФ. 2011. № 21. Ст. 2930.

3. Постановление Правительства Российской Федерации от 19.08.2011 № 694 «Об утверждении методики осуществления мониторинга правоприменения в Российской Федерации» // Собрание законодательства РФ. 2011. № 35. Ст. 5081 
4. Федеральный закон от 17.07.2009 г. № 172-ФЗ «Об антикоррупционной экспертизе нормативных правовых актов и проектов нормативных правовых актов» (ред. от 11.10.2018) // Собрание законодательства РФ. 20.07.2009. № 29. Ст. 3609.

5. Постановление Правительства от 26.02.2010 г. № 96 «Об антикоррупционной экспертизе нормативных правовых актов и проектов нормативных правовых актов» // Собрание законодательства РФ. 08.03.2010. № 10. Ст. 1084.

6. Бородина О.А. Перспективные направления деятельности органов прокуратуры в активизации института независимой антикоррупционной экспертизы // Актуальные проблемы российского права. № 1. Январь 2021.

7. Закон Тамбовской области от 23.06.2006 № 51-3 «О правовых актах Тамбовской области» (ред. от 01.12.2020) // Тамбовская жизнь, № 162-163. 07.07.2006.

8. Закон Краснодарского края от 06.06.1995 № 7-К3 «О правотворчестве и нормативных правовых актах Краснодарского края» (ред. от 09.12.2019) // Информационный бюллетень ЗС Краснодарского края, № 3, 1995.

9. Закон Свердловской области от 17.10.2013 № 84-О3 «О мониторинге законодательства Свердловской области и мониторинге практики его применения» (ред.07.12.2017) // Собрание законодательства Свердловской области. 27.11.2013. № 10 (2013). Ст. 1683.

10. Закон Республики Алтай от 04.10.2012 № 49-Р3 «О мониторинге правоприменения нормативных правовых актов в Республике Алтай» // Сборник законодательства Республики Алтай. N 92(98). Ч. 1. Сентябрь, 2012. С. 9

11. Закон Липецкой области от 05.12.2008 г. № 213-О3 «О мониторинге правоприменения нормативных правовых актов Липецкой области и нормотворческой деятельности» (ред. от 26.12.2016) // Липецкая газета. 16.12.2008. № 241.

12. Закон Республики Крым от 29.12.2016. № 340-ЗРК «О мониторинге нормативных правовых актов» // Ведомости Государственного Совета республики Крым. 09.03.2017. № 1.

13. Постановление Правительства Астраханской области от 29.09.2011. № 393-П «О мониторинге правоприменения» (ред. от 29.12.2014) // Сборник законов и нормативных правовых актов Астраханской области. 06.10.2011. № 43; Постановление Губернатора Астраханской области от 26.10.2011 № 415 «О государственноправовом управлении администрации Губернатора Астраханской области» // Сборник законов и нормативных правовых актов Астраханской области. 03.11.2011. № 47. 